\title{
Regional Metallogenic Characteristics and Prospecting Potential of Uranium Deposits in Southwest Area China
}

\author{
Ning Guo ${ }^{\mathrm{a}}$, Shi Tan ${ }^{\mathrm{b}}$, Zheng Yang ${ }^{\mathrm{c}}$ \\ Xichang College, Xichang, Sichuan, China, 615013 \\ ae-mail: 18981561978@189.cn, be-mail:shitan0717@163.com, e-mail:yzsd1989@yeah.net
}

\begin{abstract}
Keywords:uranium metallogenic belts;uranium metallogenic prospective belts;metallogenic characteristics;prospecting potential;southwest area china.

Abstract:The uranium resources prospecting started in 1955, xx uranium deposits has been prospected, and 5 uranium ore fields has formed in southwest area. According to the regional uranium metallogenic characteristics and the class of tectonic units in control region, combining concentration degree of uranium deposits, uranium mineral occurrence and mineralized spot, the region can be divided into five uranium metallogenic belts including Gangdise-Tengchong, Sanjiang, northwestern Sichuan, northern Sichuan, central Guizhou and four uranium metallogenic prospective belts including Gangdise, Qamdo, Changtai-Daocheng and Xikang-Yunnan axis.It is considered that the uranium geological metallogenic conditions are favorable besed on researches onmetallogenic characteristics of main uranium metallogenic belts. The breakthrough direction is to expand old mining areasand toopen up new bases.
\end{abstract}

\section{Introduction}

Southwest area includes the Sichuan province, Yunnan province, Guizhou province, Tibet Autonomous Region and Chongqing municipality. The geographical coordinates are at the east longitude $78^{\circ} 24^{\prime} \sim 110^{\circ} 00^{\prime}$ and the north latitude $21^{\circ} 00^{\prime} \sim 36^{\circ} 31^{\prime}$. The length is about $1820 \mathrm{~km}$ from north to south and the width is about $3250 \mathrm{~km}$ from west to east. And the total area is about $235.46 \times 104 \mathrm{~km}^{2}$. As a lot of sections are high-abrupt and in-depth, regions of above $2000 \mathrm{~m}$ altitude occupy a half of the total area. This region is one of the hardest regions for geological work in China.

\section{The exploration degree and result of uranium resources}

The geological work of uranium deposits in southwest area started in 1995. So far, there are 11 prospecting teams and almost ten thousands people engaging in geological survey and prospection of uranium ore. According to statistics of the geological survey of uranium ore the geologists completed the ground gamma and gamma energy spectrum measurement of $98.09 \times 104 \mathrm{~km}^{2}$, the aviation gamma and gamma energy spectrum measurement of $27.52 \times 104 \mathrm{~km}^{2}$, the hydration regional geological survey of more than $12.52 \times 104 \mathrm{~km}^{2}$, the track etching method measurement of $1323 \mathrm{~km}^{2}$, the polonium method measurement of $1.74 \times 104 \mathrm{~km}^{2}$, the uraniumetric measurement of $4.21 \times 104 \mathrm{~km}^{2}, \alpha+\beta$ measurement of $942.3 \mathrm{~km}^{2}$, the emanation measurement of $203.7 \mathrm{~km}^{2}$, the automobile gamma measurement of $2.90 \times 10^{4} \mathrm{~km}$, automobile gamma energy spectrum measurement of $10.02 \times 104 \mathrm{~km}$, the electrical sounding profile of $715 \mathrm{~km}$, shallow earthquake measurement of $85.6 \mathrm{~km}$, the magnetic measurement of 3058 gauging point; In terms of the uranium ore exploration, the geologists put into trenching of $264.89 \times 104 \mathrm{~m}^{3}$, exploratory shaft sinking of 
$8.51 \times 104 \mathrm{~m}$, adit exploration of $15.92 \times 104 \mathrm{~m}$, drilling of $223.88 \times 104 \mathrm{~m}$.

Thanks to the hard work of many geological workers of uranium ore, they have verified $\mathrm{xx}$ uranium deposits, XXX ore occurrence, xxx mineralized points, xxxx uranium anomaly belts in southwest area, and submitted and controlled an amount of uranium resources through the half-century regional geological survey, reconnaissance, exposing and prospecting of uranium ore.

\section{Industrial uranium deposit types and spatial distribution}

It has been verified that industrial uranium deposit are composed of sandstone type, carbonate-siliceous-pelitic type, alkaline rock type, phosphorite type and granite type in southwest area. Among them, the sandstone-type uranium resources account for $49.0 \%$ of the total and carbonate-siliceous-pelitic type account for 38.3\%. Both types are dominant in the quantity of uranium deposits and resource (Fig.1). Verified uranium resource distributes in Yunnan, Sichuan and Guizhou province (Fig.2). Five Uranium orefields including Linchang, Tengchong, northern Sichuan, Ruoergai and Certral Guizhou ${ }^{[1,2]}$ are formed, which establish the basic pattern of uranium resources base in southwest China.

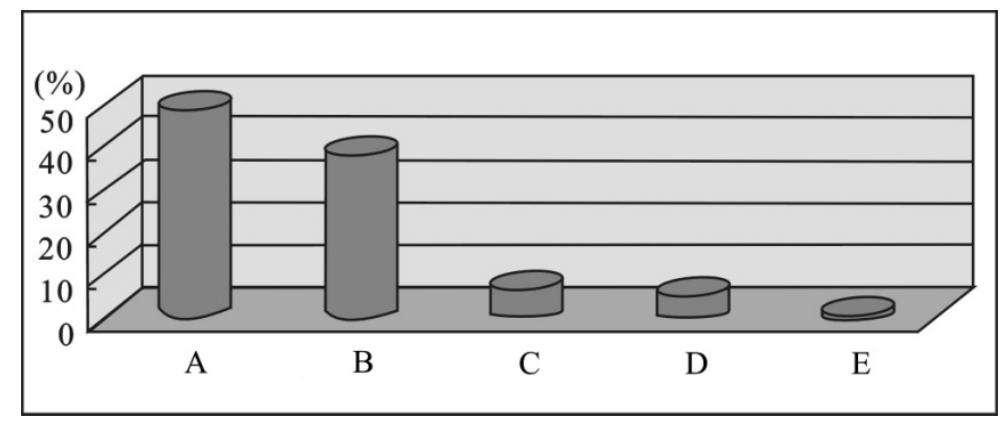

Fig.1 Scale drawing of industrial uranium deposit types and quantity of resources in southwest area of China. A - Sandstone type;B - Carbonate-siliceous-pelitic type;C-Alkaline rock type;D_Phosphorite type;E-Granite type.

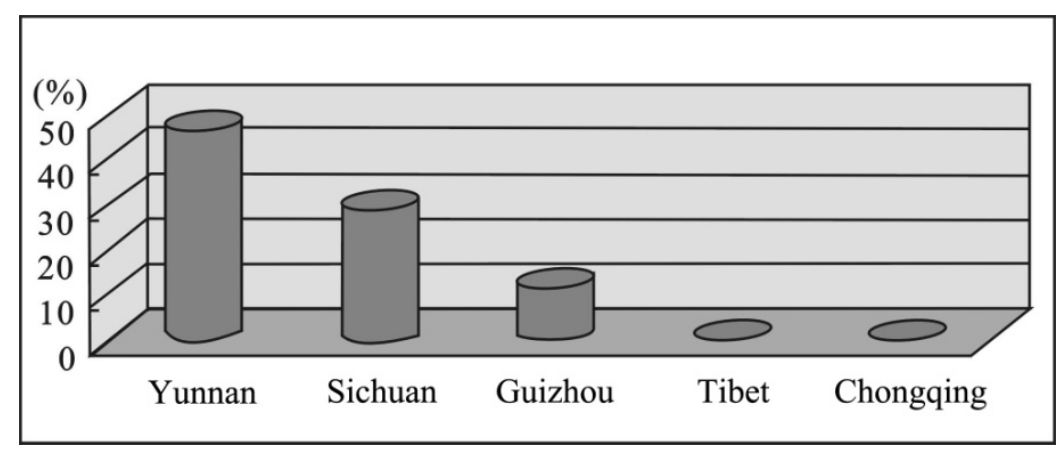

Fig.2 Scale drawing of uranium resources in different provinces, municipalities, autonomous regions in southwest area of China

\section{The basic outline of regional structure and uranium metallogenic belt division}

Southwest region is located in two tectonic domains Tethys and Shore of the Pacific (the northwest of Sichuan belongs to Qinling-Qilian-Kulun tectonic domain), and the first class of seven tectonic units cross the Yangtze platform, south china folding system, Qinling folding system, Bayankala-songpan folding system, Karakorum-three river folding system, Gangdise-Nianqintanggula folding system and Himalaya-Yaluzangbu river folding system ${ }^{[3]}$. 
It has been verified the uranium deposits mainly belong to both uranium metallogenic regions: Tethys and Shore of the Pacific ${ }^{[4]}$. According to the regional metallogenic characteristics, the class of controlling regional tectonic unit and concentrated degree of uranium deposits, uranium mineral occurrence, southwest area of China can be divided into Gangdise-Tengchong, three-river, northwest of Sichuan, north of Sichuan, middle of Guizhou 5 uranium metallogenic belts and Gangdise, Changdu, Changtai- Daocheng and Xikang-Yunnan axis 4 uranium metallogenic prospective belts (Table1, Fig.3)

Table 1 Statistical uranium metallogenic belts division table in southwest area of China (modified from HUANG Jingbai etc. 2005)

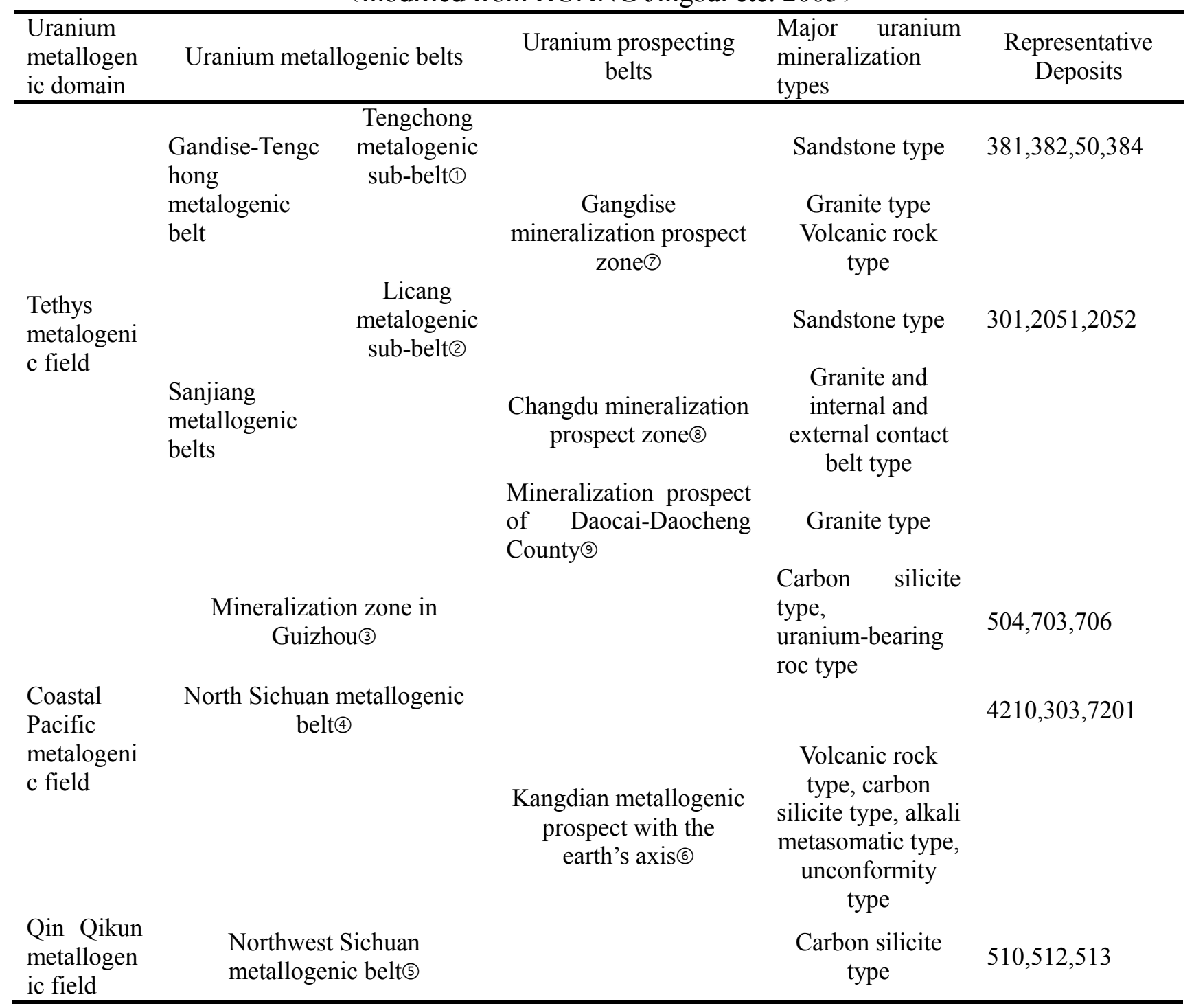




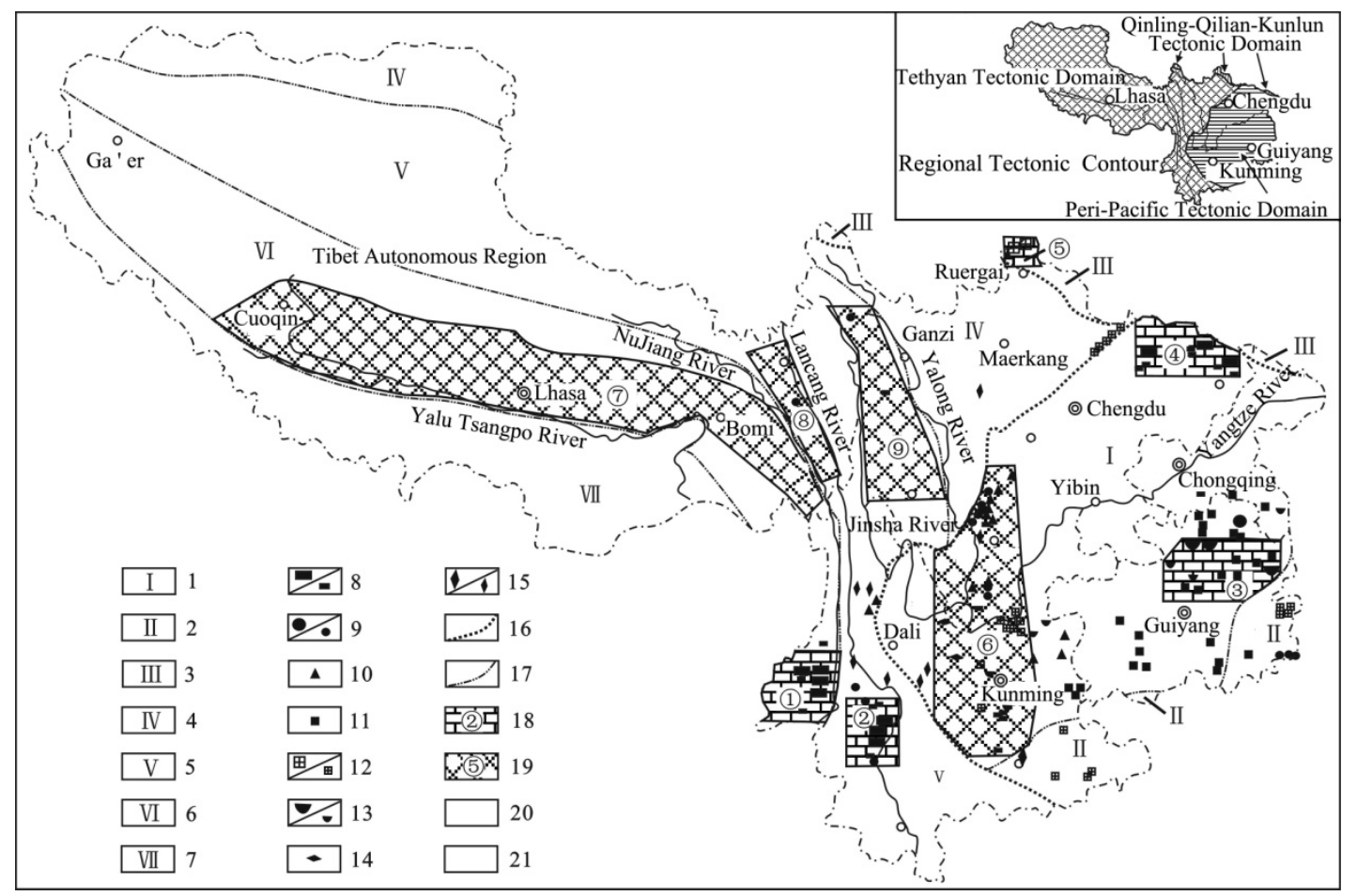

Fig.3 Sketch of uranium metallogenic belts division map in southwest area of China

1-Yangtze platform;2 - south china folding system;3-Qinling folding system;4—Bayankala-songpan folding system;5-Karakorum-three river folding system;6-Gangdise-Nianqintanggula folding system;7-Himalaya-Yaluzangbu river folding system;8-sandstone type uranium deposit/uranium mineral occurrence;9-granite type uranium deposit/uranium mineral occurrence;10 - volcano rock type uranium mineral occurrence;11-carbonate type uranium mineral occurrence;12-Carbonaceous-siliceous-argillitic rock type uranium deposit/uranium mineral occurrence;13 - contain the uranium phosphorite type uranium deposit/uranium mineral occurrence;14 - metamorphic rock type uranium mineral occurrence;15-alkalic rock type uranium deposit/uranium mineral occurrence;16-tectonic domains boundary;17-the 1st class tectonic units boundary;18 - uranium metallogenic belts and number;19-uranium metallogenic prospective belts and number

\section{The main regional uranium mineralization characteristics of metallogenic belt}

\section{Gangdise-Tengchong metallogenic belts-- Tengchong metallogenic belt}

Tengchong metallogenic belt is located in the West Area of Nujiang in Yunnan province.The geotectonic position belongs to the southern part of Gangdise-Nyain qentanglha fold system fold system. In the view of plate theory point, it is located in the east of India plate and Eurasian plate suture -- the tengchong microplate ${ }^{[5,6]}$. Mineralized rock system is built by the continental faice clastic rock of the Neogene Pliocene Mangbang Formation. The type of uranium mineralization is sandstone type of phreatic aquifer oxidation zone ${ }^{[7]}$. The length of metallogenic belt is $200 \mathrm{~km}$ from north to south and width is $30 \sim 50 \mathrm{~km}$ from east to west. It is formed by $\mathrm{x}$ deposit, $\mathrm{xx}$ mines, $\mathrm{x} x$ uranium mineral occurrence, and it constitutes one of the most important sandstone-type uranium metallogenic belts in China (Fig.4). 


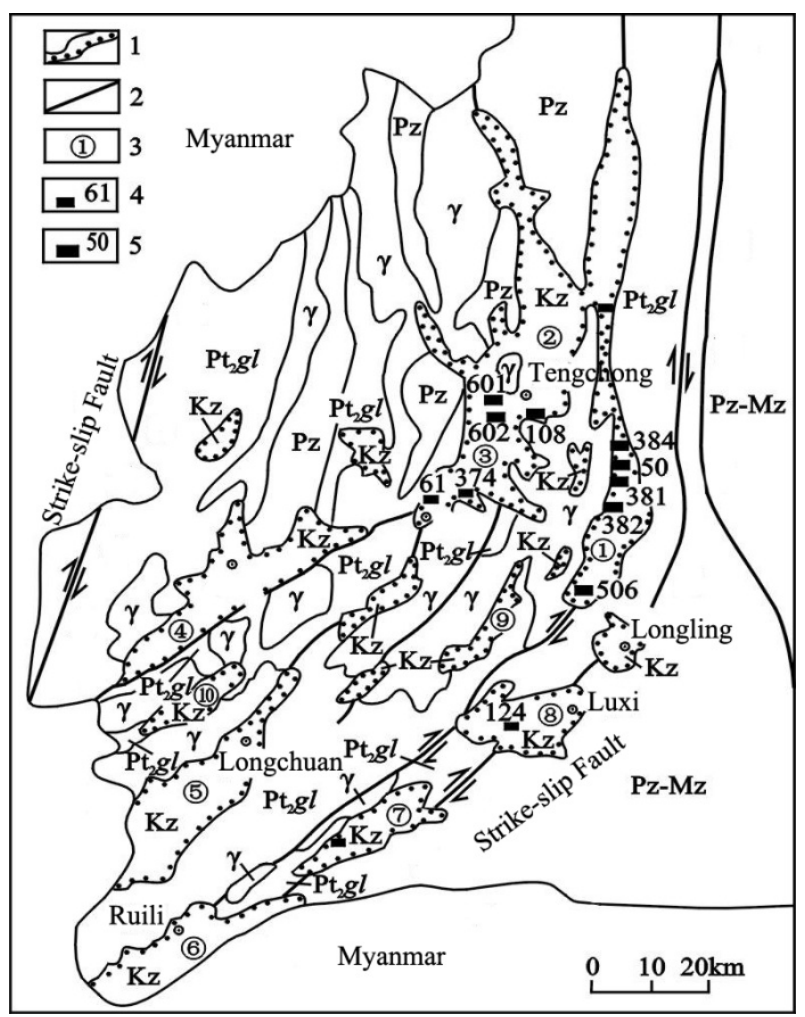

Fig.4 Rough sketch of uranium geologic map of Tenchong microplate ${ }^{[8]}$

$\mathrm{Kz}$-Cenozoic;Mz-Mesozoic;Pz-Paleozoic; $\mathrm{Pt}_{2} \mathrm{gl}$ - Mesoproterozoic Gaoligongshan Group; $\gamma$ - granite; 1 -geological boundary and unconformable boundary;2-fault;3 - the number of basins((1) — Longchuanjiang basin;(3 — Tenchong basin;(3) — Lianghe basin;(4) — Yingjiang basin;(5 —-Longchuan

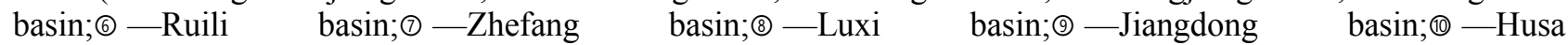
basin);4-sandstone-type uranium mineral occurrence and number;5-sandstone-type uranium deposit and number

It has been verified that uranium deposits are mainly located at the basal slope belt and ore deposit is located in neogene Mangbang Formation on top of the alluvial fan body ${ }^{[9]}$. Sedimentary thickness of Mangbang Formation is more than $1000 \mathrm{~m}$, which is divided into three sections and six layers according to its sedimentary characteristics. Main ore bodies occur in the 2nd bed of lower member and the 1 st bed of middle member with gravel braided channel sand body of alluvial fan sedimentary system, and the mouth bar and distributary channel's sedimentary sandstone body of fan delta sedimentary system also contains a part of uranium ore bodies.

Through drilling, it can be verified that clastic rock of deep Mangbang Formation suffered oxidation alteration and then formed oxidizing zone. According to cause of oxidation zone, it can be divided into two types: the phreatic oxidized zone and the phreatic interlayer oxidation zone. Among them, the development scale of the phreatic interlayer oxidation zone is the largest with $1 \sim$ $3 \mathrm{~km}$ width and $30 \sim 120 \mathrm{~m}$ thickness.

Distribution direction of the phreatic interlayer oxidation zone can directly control space distribution of uranium ore body (Sun Zequan et al, 2006). In the slope belt, the uranium ore body is located in forward and upper and lower wing of the phreatic oxidation (Fig.5a); in rift zone, the uranium ore body is located in forward and upper wing of the phreatic interlayer oxidation zone (Fig.5b); and only uranium mineralization can be found in the lower wing of the phreatic interlayer oxidation zone, where industrial uranium ore body has not been found. 

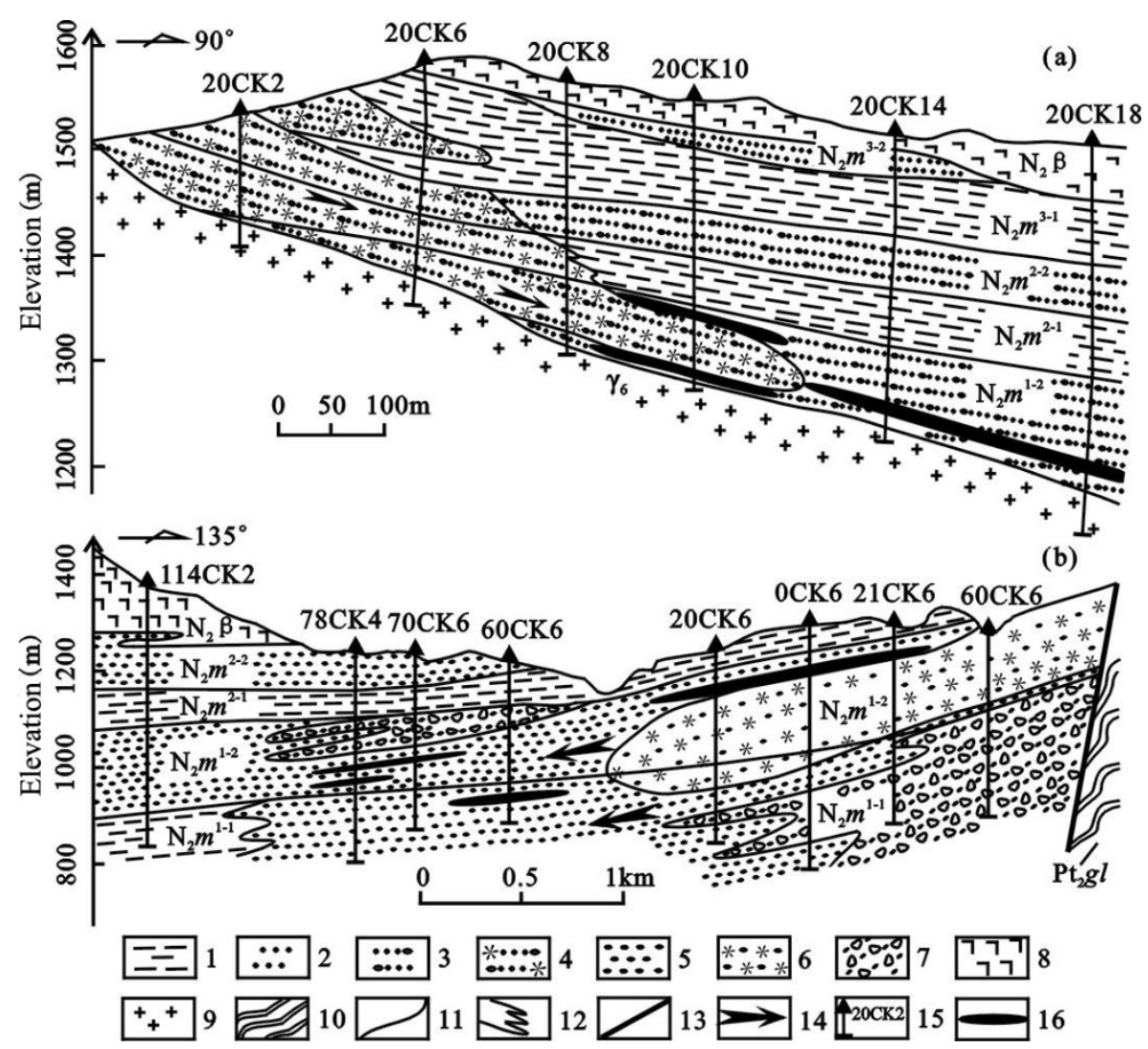

Fig. 5 Section view of the uranium deposit prospecting lines in Longchuanjiang basin ${ }^{[8]}$ a - the uranium deposit prospecting profile No.20 in slope zone;

$\mathrm{b}$ - the prospecting baseline profile of uranium deposit in rift zone

Pliocene Mangbang formation: $\mathrm{N}_{2} m^{3-2}$ - the 2nd bed of upper member; $\mathrm{N}_{2} m^{3-1}$ - the 1st bed of upper member; $\mathrm{N}_{2} m^{2-2}$ - the 2nd bed of middle member; $\mathrm{N}_{2} m^{2-1}$ - the 1 st bed of middle member; $\mathrm{N}_{2} m^{1-2}$ - the 2 nd bed of lower member; $\mathrm{N}_{2} m^{1-1}$ - the $1 \mathrm{st}$ bed of lower member; $\mathrm{N}_{2} \beta$-Pliocene basalt; $\gamma_{6}$ - Himalayan granite; $\mathrm{Pt}_{2} g l$-Mezoproterozoic Gaoligongshan Group;1-mudstone and siltstone;2-sandstone;3 - pebbly sandstone;4-oxidated pebbly sandstone;5-sandstone and glutenite;6-oxidated sandstone and glutenite;7—conglomerate;8—basalt;9-granite;10 - metamorphic rock;11—geological boundary;12—phase boundary;13 - fault;14 - direction of groundwater flow;15 - location and number of drill;16 - uranium orebody.

Using the uranium-lead radiometric dating back to the measurement of the isotopic ages of pitchblende of four deposits, it was found that the metallogenic time was between 0.5-5.0 Ma ${ }^{[10,11]}$ and the ceiling age of old-bearing strata formation is $5.2 \mathrm{Ma}$. Thus, sandstone-type uranium deposits of Tengchong metallogenic subzone belong to exogenous and epigenetic sandstone-type uranium deposits of the phreatic interlayer oxidation zone.

\section{Metallogenic belts of the northern Sichuan}

Metallogenic belts of the northern Sichuan is located in Nanjiang, Tongjiang and Xuanhan area in the north of Sichuan basin. Geotectonic position is located in the Yangtze platform of Sichuan depression and the platform subside of the northern Sichuan at East-West direction. The ore-bearing rock formations are built by the continental clastic rock of upper Jurassic Penglaizhen formation and lower Cretaceous Cangxi formation. The uranium mineralization is sandstone type of interlayer oxidation belt. Metallogenic belt is about $240 \mathrm{~km}$ long and $40 \sim 50 \mathrm{~km}$ wide, formed by X uranium deposits, XX mineral occurrences, XX uranium mineralized points.

Verified uranium deposits are located in down-warped basin edge and it is close to the front edge of Daba-Micang Mountains. Uranium ore body is positioned in $0 \sim 20 \mathrm{~m}$ upper or lower regional disconformity surface of the Cangxi and Penglaizhen formation.

River-delta deposit system was developed in Penglaizhen and Cangxi formation. Host rocks of uranium is lag-deposit sandstone in the riverbed of low and high sinuous river. 
Regional disconformity surface of the Cangxi and Penglaizhen formation is the channel of groundwater movement. It is beneficial to migrate groundwater with oxygen and uranium, thereby developing interlayer oxidation zone. Uranium precipitated and concentrated to mineralization in the transitional redox zone. The redox potential of dark grey mineral sandstone in the transitional redox zone $\triangle \mathrm{Eh}=30 \sim 60 \mathrm{mV}$, reduction coefficient $\mathrm{Fe} 2+/ \mathrm{Fe} 3+=1.56 \sim 2.63^{[2]}$.

Uranium mineralization is closely related with organic matter (Fig.6). When the organic content is higher, the uranium mineralization is better.

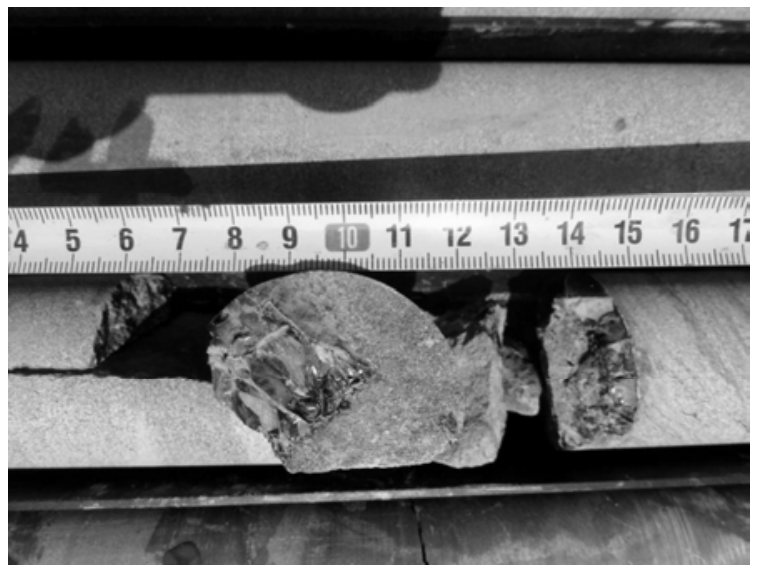

Fig.6 Core photo of massive organic matters in uranium mineralization section

The formative age of regional disconformity surface between the Cangxi and Penglaizhen formation is $140 \mathrm{Ma}$. The formative ceiling age of Cangxi formation is $107 \mathrm{Ma}$ and metallogenic age is $84 \mathrm{Ma}, 81 \mathrm{Ma}$ and $71 \mathrm{Ma}^{[2]}$, respectively. The time interval between the ages of host rock is $23 \sim 36 \mathrm{Ma}$. All these show that uranium mineralization of metallogenic belts in Northern Sichuan is characterized by multiphase and multi-stage.

\section{Northwest Sichuan metallogenic belt}

Northwest Sichuan metallogenic belt is located in Diebu and Ruoergai at junction of Sichuan and Gansu province. And the geotectonics is located in the linking position of Garzê-Songpan folding system and Qinling folding system. Uranium deposits are mainly distributed in the Bailongjiang anticlinorium of the West Qinling folding system (Fig.7). Ore-bearing rock formations are constructed by marine siliceous limestone of Yangchang, Taer and Lalong formations in lower Silurium Series. And Uranium mineralization is Carbonate-Siliceous-pelitic rock type. Metallogenic belt is expanded along east-west direction with over $100 \mathrm{~km}$ length and about $5 \sim 10 \mathrm{~km}$ width, constituted by $\mathrm{x}$ deposits, $\mathrm{xx}$ ore occurrences and $\mathrm{xx}$ mineralized spots. 


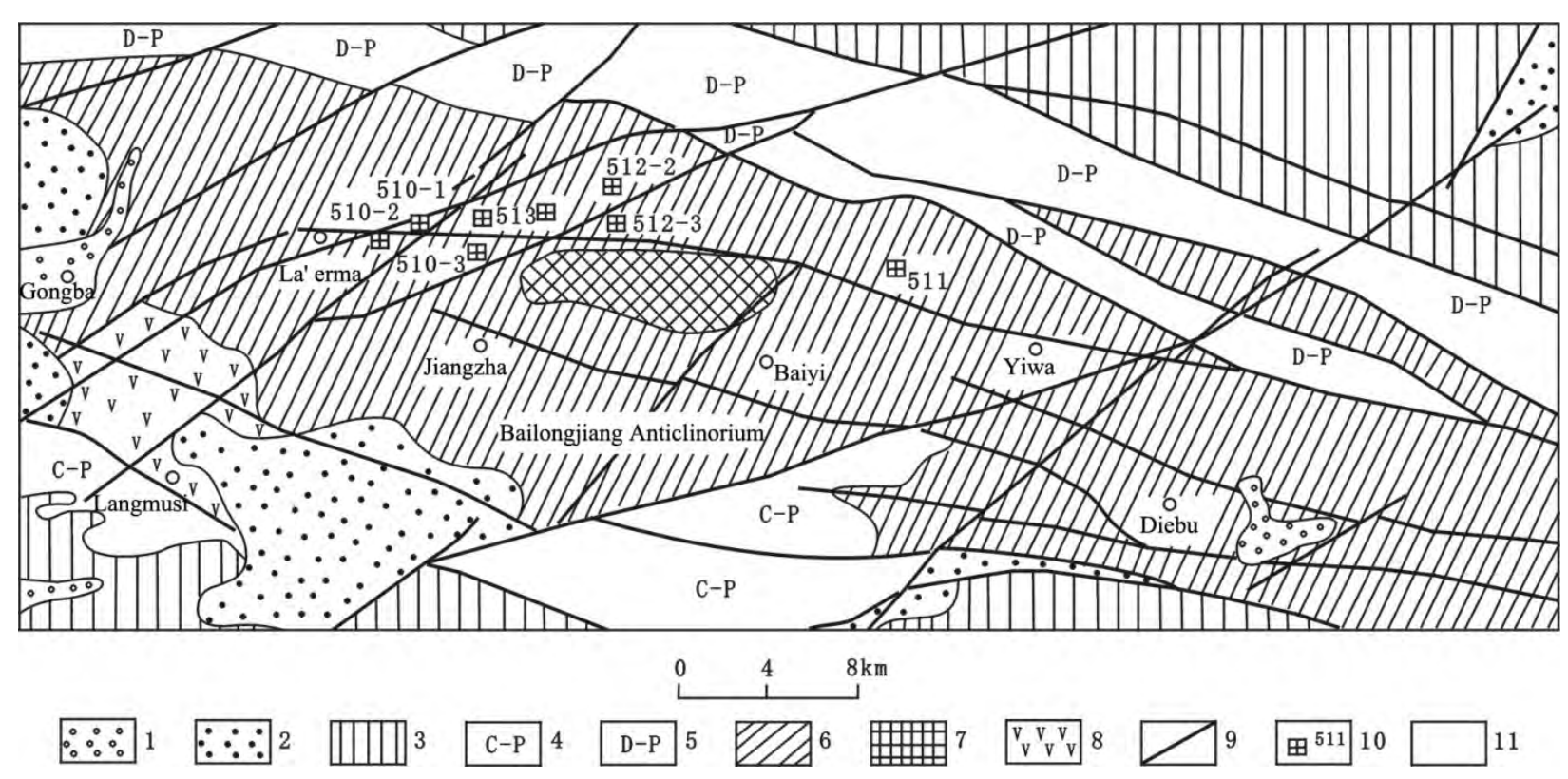

Fig.7 Sketch geologic map of Zoige uranium ore field

1-Qnartemary System ;2-Cretaceous System;3-Triassic System;4-Carboniferous-Permian System;5-Devonian-Permian System;6-lower Silurium Series;7-Sinian System Baiyigou group;8-Jurassic volcano rock;9-fault fracture; 10 - uranium deposit and number

The sedimentary system analysis showed that the shelf sedimentary environment is in lower Silurium Series of ore rock ${ }^{[12]}$, and the sedimentary environment changed between the inner shelf and outer shelf because of rising and falling of sea level. It led to the rock rhythm combination of the sandstone, the slate-siliceous rock, limestone - sandstone and slate, which provide a favorable lithological association for uranium mineralization; The geochemical characteristics of ore rocks showed that the original sedimentary silica formed with participation of abyssal hydrothermal or far-source volcanic hot water $^{[12]}$. The original sedimentary limestone and silicon rock have experienced a multi-phase structure, hydrothermal transformation after the diagenesis, providing not only conditions for uranium preconcentration and remobilization, but also a favorable space for the late mineralization.

The altered mineral assemblage of typical uranium deposits has the vertical zoning of "upper acid and lower base" ${ }^{[13]}$. The upper part of the deposit is "acid cap", where silicification is developed; the middle is "acid-base symbiotic zone" where silicification and carbonation are more developed; and the lower part is "alkaline base",where carbonatation happened .

The trace elements, rare earth elements and stable isotopic characteristics of hydrothermal minerals (calcite, quartz, pyrite, etc.), which are closely related to uranium mineralization, showed that the geochemical interface of acid-base seperation about $200 \mathrm{~m}$ depth from the earth's surface which gathered a variety of trace elements ${ }^{[13]}$, and was a part where sudden uranium mineralization happened and became very rich. Fluid, mineralizer $(\Sigma \mathrm{CO} 2)$ and heat source were mainly derived from crust-mantle mixed fluid and mantle. The mineralization process is that $\Sigma \mathrm{CO} 2$-rich and uranium-rich metallogenic hydrotherm rose to a part where pressure suddenly decreased, resulted in decompression boiling and sudden precipitated to form uranium deposits.

Mao Yunian ${ }^{[14]}$ have determined that the age of pitchblende is $90 \mathrm{Ma}$ and $60 \mathrm{Ma}$. Jin Jingfu ${ }^{[15]}$ have measured that the age of quartz ESR (electron spin resonance) in the 510 and 512 uranium mineralization stage is $89.75 \mathrm{Ma}$ and the $\mathrm{Pb}-\mathrm{Pb}$ isochron age of rich uranium ore is 61.43 $\mathrm{Ma}$, which are consistent with the results of Mao Yujun ${ }^{[14]}$. It can be seen that the uranium mineralogenetic epoch in the northwest Sichuan metallogenic belt is mainly concentrated at $90 \mathrm{Ma}$ and $60 \mathrm{Ma}$, and the two stages of mineralization coincided with tectonic-magmatic activation 
caused by the Upper Cretaceous and Eocene movement in the area, that is, crust extensional movement.

\section{Prospects analysis of prospecting}

It has been mentioned that the southwestern region is located in the Tethys and marginal-Pacific two tectonic domains, across seven first-order tectonic units. The stratum are well developed. The magmatic activity is frequent. The fault structure develops and the metamorphism are complex and diverse in the area. This complex regional geological background determines that the tectonic units have undergone different stages of developing evolution of the crust. and that characteristic dominant minerals may form in different crust evolutionary process or even different stages of evolution and uranium ore is not the exception. The uranium geological metallogenic conditions in the southwest are favorable. The mineralization types are diversified and the potential uranium resources are in large quantities. There is still hope that the amount of verified uranium deposit resources expands. There are many areas where uranium resource potential has not yet been estimated. New types of uranium mineralization need to be explored. The conclusion is that "expand old diggings and open up new bases."

\section{Expand old diggings}

There is possibility that the amount of resources in metallogenic belts in southwest China is widened. The expansion of resources includes two aspects as followed:

One is to greatly strengthen deep ore prospecting. Recently studies and explorations have showed that the apothem of a majority of deposits within metallogenic belts in the northwest Sichuan can reach more than $500 \mathrm{~m}$. For example, when the apothem of 510 deposit reaches $700 \mathrm{~m}$, that of 512 deposits is more than $800 \mathrm{~m}$, and the control depth of most ore bodies is only about $250 \sim 300 \mathrm{~m}$. The prospecting depth of the sandstone-type uranium deposit in the Tengchong metallogenic subzone and Lincang metallogenic subbelt is no more than $300 \mathrm{~m}$. Therefore, prospecting in the deep ground of above metallogenic belts is very prospective.

The second is to find new types of uranium mineralization in the metallogenic belts. The preferable uranium occurences (belts) have been found in the acid volcanic rocks in middle-lower Jurassic in the Langmusi-Gompa area within Northwestern metallogenic belts, and as volcanic rocks and intermediate acid intrusive rocks in the area are homologous but heteropical products, uranium mineralization may belong to another metallogenic mechanism of mantle fluid. Therefore, through further work, it is possible to find volcanic-type uranium deposits. Pitchblende and uranium black are found in the granite body heavy concentrate of Cenozoic basin provenance area Menglian and Lincang within Tengchong and Lincang metallogenic subzone. Hence granite-type uranium mineralization of its provenance area is worth exploring. The uranium content of the Neogene granulite gravel of the Lianghe basin in Tengchong metallogenic subzone is between $0.02 \%$ and $0.05 \%$, and some gravel itself is uranium ore. It can be seen that prospecting uranium mineralization occurred in the granulite is prospective in the Gaoligong Mountains in mesoproterozoic erathem of provenance area.

\section{Open new bases}

Opening up new bases is to speed up the regional assessment of the metallogenic prospect belts, thereby improving the degree of work and striving to find a number of uranium resources orefield.

Xikang Yunnan axis metallogenic prospective belt: Since 1950s when uranium geological work was carried out on the Earth's axis, a total of XX uranium ores, XX uranium mineralization point and tens of thousands of uranium anomaly points were found in the region. Due to the low-level work, uranium deposit has not yet formed in the current area. In recent years, the study showed that 
there are prospective volcanic-type uranium deposits in the northern Xiaoxiangling area, and the prospective carbon-silicite-type and alkali-metasomatic uranium deposits in the central Huili-Kunming region; while prospect of unconformity uranium deposits related to plane of unconformity of Neoproterozoic exists in Southern Jiangchuan-Jianshui area.

Changtai-Daocheng metallogenic prospective belt: According to the regional geological survey data, the gamma intensity of the Gnie complex granite body (hereinafter referred to as the Gnie rock mass) is generally about 80 gamma; the gamma intensity of two hot springs exposed to the middle or periphery of the rock mass exceeding 1000 gamma. Six hot springs are $200 \sim 800$ gamma. It is found that varying extent of asphalt uranium, uranothorite, thorium and other heavy minerals exist in natural and artificial heavy sand samples, asphalt uranium even accounting for $0.014 \%$ in some samples. In 2010, 280 Institute of Nuclear Industry carried out uranium resource potential assessment in the region, with more than $0.05 \%$ uranium mineralization found in the northern part of the Gnie rock mass. Therefore, there is prospect of prospecting granite-type uranium ore in the region.

The degree of geological work of uranium in Tibet is very low. Since 2005, 280 Institutes of Nuclear Industry carried out uranium resource potential investigation within $55 \times 10^{4} \mathrm{~km}^{2}$ in Gangdise-Qamdo, believing that there are metallogenic conditions of granite-type and volcanic-type uranium ore in the region. It is predicted that there are 6 pieces of the prospective areas including 3 first level and 3 second level. Two uranium metallogenic prospecting zones of Gangdise and Qamdo are established. In particular, the root of metallogenic prospective zone of Qamdo located in Meiyu County of Zuogong County has more uranium ores, which are composed of five mineralization sections. The uranium mineralization zone is longer than $4 \mathrm{~km}$ and the grade is rich (the highest grade is more than 10 times of the lowest industrial grade). It is preliminary estimated that there are xxxxt 334-level uranium resources. Through further work, more uranium deposits are expected to develop into above medium-sized uranium deposits.

In conclusion, with the development of new metallogenic theory and prospecting model, the application of new prospecting methods and technique, as well as the improvement of traffic and field equipment conditions, uranium resource prospection in southwest China is promising.

\section{Acknowledgements}

This work was financially supported by the national natural science fund support project (41072064), China nuclear industry geological survey geological projects ( 201365 )

\section{References}

[1] Chen Youliang. Southwest uranium resources status and prospecting prospect [J], uranium geology, 2004, 20 (1): 1-3.

[2] Jin Youzhong, Li Qingyang, Zhu Xiyang, etc. Southwest uranium geological records [R]. China Nuclear Industry Geology Bureau(2005).

[3] Cheng Yuqi . China Regional Geology [M], Beijing: Geological Publishing House(1994).

[4] Huang Jingbai, Huang Shijie. China's uranium resources regional mineralization characteristics [J], uranium geology, 2005,21 (3): 129-138.

[5] Duan Jianzhong, Tan Xiaohong. The characteristics and characteristics of the main strike-slip faults in the Sanjiang area of western Yunnan [J], Yunnan Geology, 2000, 19 (1): 8-23.

[6] Duan Jianzhong, Xue Shunrong, Qian Xianggui . The Cenozoic geological structure and its evolution in the "Sanjiang" area of western Yunnan [J], Yunnan Geology, 2001,20 (3): 243-252. 
[7] Sun Zexuan, Chen Hongde, Chenyong,etc. Phreatic interlayer oxidation zone sandstone-type uranium mineralization characteristics and mode of Inter - Western Yunnan Basin [J],2006 ,25 (2): 191-198.

[8] Sun Zexuan, Chen Hongde, Wuying etc. Study on Cenozoic basins and sandstone-type uranium deposits in western Yunnan [J], Geological Review, 52 (4): 494-500.

[9] Zhu Xiyang, Sun Zexuan, Chen Hongde etc. Sedimentary system Longchuanjiang basin sandstone type uranium mineralization [J] Chengdu University of Technology (Natural Science Edition), 2004,31 (3): 267-272.

[10] Dai Jiemin. Fracture-hot water genesis characteristics of sandstone-type uranium deposits in western Yunnan [J]. Geochemistry, 1994,23 (Suppl.): 76-83.

[11] Cai Yuqi, Li Mangen . Mineralization characteristics and genesis of sandstone-type uranium deposits in the central and southern Longchuanjiang basin, western Yunnan [J]. Journal of East China Institute of Geology, 2002, 25 (2): 124-127.

[12] Chen Yuliang, He Mingcai, Zhu Xijian,etc. Study on rock characteristics and genesis of ore-bearing rock series in Ruoergai uranium orefield [J], Journal of Chengdu University of Technology (Natural Science Edition), 34 (5): 69-74.

[13] Chen Yueliang. Ruoergai area carbon silicite mudstone uranium deposit ore-forming fluid genesis and metallogenic model [D], Chengdu University of Technology doctoral dissertation (2008).

[14] Mao Yuxian, Min Yongming. West Qinling Lithosilicate mudstone type uranium [M]. Beijing: Geological Publishing House(1989).

[15] Jin Jingfu, He Mingyou, Wang Deyin . Study on metallogenic regularity and prospecting criteria of concealed uranium deposits in Ruoergai area [R]. Chengdu Institute of Technology scientific and technological achievements report (1994). 